Our Nature (2010) 8:12-25

\title{
Nesting Ecology, Interspecific Interaction and Nesting Association of Indian Black Ibis (Pseudibis papillosa) Inhabiting the Arid Zone of Rajasthan
}

\author{
K.C. Soni ${ }^{1 *}$, A.N. Sharma ${ }^{1}$ and V.C. Soni ${ }^{2}$ \\ ${ }^{1}$ Department of Zoology, Lohia P.G. College, Churu (Rajasthan)- 331001, India \\ ${ }^{2}$ Department of Biosciences, Saurastra University, Rajkot (Gujarat), India \\ *E-mail: kcsibis@yahoo.com
}

Received: 15.06.2010, Accepted: 21.10.2010

\begin{abstract}
The nesting ecology, interspecific interaction and nesting association of the Black Ibis (Pseudibis papillosa) were studied during the 2003-2006 breeding season in $400 \mathrm{~km}^{2}$ area in and around Churu city of Rajasthan, India. Total 28 nest sites of the Black ibis were located within the study area. Majority of the nest sites were located in the heart of rural and urban area and nearby feeding sites but in rainy season the Black ib is prefers to nest in outskirt of rural and urban area. Among 28 nest sites $14(50 \%)$ nest sites were permanent in nature while $14(50 \%)$ were temporary in nature. Among permanent 14 nest sites, 7 (50\%) were found in rural area and 7 (50\%) in urban area. The similar ratio was found for temporary nesting sites. The Black ibis more frequently preferred nest on tallest available tree with highest relative density, canopy cover and DBH at nest site. The average nest tree height was $8.19 \pm \mathrm{SD} 1.39 \mathrm{~m}$ above ground. The nesting tree height was found to vary from 4.81 to $13.00 \mathrm{~m}$. The nest position from the ground was at an average of $6.88 \pm \mathrm{SD} 1.19 \mathrm{~m}$. The nest height varied in the range of 3.84 to $11.02 \mathrm{~m}$. The average canopy cover was $5.67 \pm \mathrm{SD} 1.11 \mathrm{~m}$. The canopy cover was in the range of 3.09 to $9.73 \mathrm{~m}$. Average data on DBH was also observed with an average of $0.63 \pm$ SD0.18 m. The DBH noted to vary in the range of 0.43 to $1.16 \mathrm{~m}$. Trees selected to nest showed significant correlation between the height and canopy cover $(0.872243, \mathrm{p}=5 \%)$, and total heights of the trees and the nest heights $(0.932416, \mathrm{p}=1 \%)$. Characteristics such as tree height, canopy cover, and nest height of the trees used for nesting once or many times were observed. All observed nests of the ibis were found to locate on the third subbranch of the trees. Nest placement on the sub-branch of the tree was found with an average of $2.85 \pm \mathrm{SD} 0.32 \mathrm{~m}$ from the end of the trunk. The numbers of flight pathways at each nest site were also counted and it was found with an average of $2.71 \pm$ SD 0.7 and it varied in the range of 1 to 4 . The Black Ibis nests singly, usually high in a tree such as a peepal or neem, nearly always occupying an old nest of a bird of prey, a vulture or a crow or a kite. Often the tree is very close to human habitation. Nests are often used annually in spite of nest failures due to harassment by House and Jungle Crows.
\end{abstract}

Key words: Nesting ecology, Black ibis, Arid zone, Rajasthan, India.

\section{Introduction}

Selection of the nest site is often considered as an important determinant of reproductive success in many bird species (Coulson, 1968; McCrimmon, 1980; Ryder and Ryder,
1981; Jackson et al., 1988; Rendell and Robertson, 1989; Li and Martin, 1991; Toumenpuro, 1991; Donazar et al., 1994; 1996). Kushlan (1976) reported role of 
availability of feeding sites in nest site selection in White ibis. In some ibises, reduced reproductive success was recorded due to poor nest site selection (Burger and Miller, 1977; Frederick, 1986; 1987). Study of nest site selection in birds may lead to design conservation strategy. Nest site selection is closely related to individual fitness since it influences the probability of successfully raising offspring (Martin, 1988). The poor nest site selection leads to nest predation and hence affect the natural selection of the bird species (Lack, 1954; Ricklefs, 1969; Nillson, 1984). Factors such as inclement weather and proximity to feeding places may also influence bird species of small body size. Larger species are better to tolerate weather oscillations and can make long distance trips in search of food (Collias and Collias, 1984). Many avian studies have shown intraspecific variations in breeding success in relation to nesting substratum. Nests made at the places not easily accessible to predators, such as cliffs, tall trees, thick vegetation, have high breeding success (Ames and Merserau, 1964; Simmons and Smith, 1985; Burger, 1984; Martin and Rooper, 1988; Dunham, 1990; Li and Martin, 1991; Alonso et al., 1991; Watson, 1992; Kelly, 1993). Since selection pressure for nest sites is intense, the choice of less safe places is very common. As a rule, such a choice could occur when competitive pressure for the best sites is very strong. The individuals with lesser competitive abilities would then be relegated to suboptimal sites (Brown, 1969; Alatalo et al., 1985; Nillson, 1987; Li and Martin, 1991; Newton, 1991; Dhondt et al., 1992). Breeding habitat is of prime importance for the fitness of individual birds (Martin, 1988; Boulinier, 1996). In a given species, nest site quality varies in space and time at different scales due to different environmental factors affecting reproductive success (Wiens, 1976). According to the current theory, the distribution of individuals among patches of varying qualities should correspond to an ideal free or an ideal despotic distribution depending on the type of territory competition existing among individuals (Fretwell and Lucas, 1974).

Nest site selection of colonial ibises nesting in mixed species heronries was studied by Kushlan (1976), Burger and Miller (1977) and Burger (1978a, 1978b, 1979). However, nesting requirements of the Black ibis is poorly known except brief accounts given by Ali and Ripley (1983), Lathigara (1989), Hancock et al. (1992), Soni and Sharma (2008), Soni (2008). A few sittings of nesting of Black ibis in Kota district have been observed by Nair and Vyas (2003). Nesting ecology of the Black ibis was studied to understand the factors affecting selection of nesting habitat and nest tree and its implications for management of the species for conservation purpose.

Utilization of similar limited resources by more than one coexisting species results in competition among them (Koplin and Hoffmann, 1968) or resource partitioning (Schoener, 1974). Interactions among coexisting species may commonly occur in nature, but it is rarely conspicuous and so less often described. According to MacArthur and Levis (1967), competition between the species occurs more frequently when overlap in resources use in coexisting species is greater. Therefore, measurements of niche overlap often used to describe competition.

The Black ibis (Pseudibis papillosa), Pariah kite (Milvus migrans) and Crow 
(Corvus splendens) are coexisting resident birds and usually nest solitarily (Ali and Ripley, 1983). A close association of these species was observed in the study area. Interspecific interactions between two species could be expected since Ali and Ripley (1983) reported that Black ibis often use deserted nest of Kites and Vultures. While studying the nesting ecology of the Black ibis, interspecific interactions were observed between the said species. Avian breeding colonies represent temporally and spatially predictable food resources for predators. However, colonial breeding usually reduces predation impact through dilution effects and communal defense (Bertram, 1978; Wittenberg and Hunt, 1985). In addition, protective nesting associations with birds of prey (Collias and Collias, 1984) have been described as a mechanism for defending nests against predators (Cain and Hilgarth, 1974; Wiklund, 1982; Bogliani et al., 1992; Norrdahl et al., 1995). Despite the widespread occurrence of a protective nesting association in some groups of birds (Collias and Collias, 1984), few descriptions are available in the literature for Ciconiiformes species (Boulinier, 1996; Donazar et al., 1994; 1996; Bouton and Bouton, 2001). Study of the extent of niche overlap and interspecific interactions between the species was carried out in attempts to find importance and mechanism of interactions. Additionally, we noted that, nesting association in ibises reduced nest predation, and breeding success was high when nesting occurred nearer aggressive raptors (Soni and Sharma, 2006).

\section{Materials and methods}

The nesting ecology of the Black Ibis (Pseudibis papillosa) was studied during the
2003-2006 in $400 \mathrm{~km}^{2}$ area in and around Churu city of Rajasthan, India $\left(29^{\circ} \mathrm{N}, 75^{\circ} \mathrm{E}\right.$ and $286 \mathrm{msl}$ ). The annual rainfall in the area is $325 \mathrm{~mm}$. Total 120 days of observation were made for five pairs during the breeding season. Nests built on neem (Azadirachta indica) and peepal (Ficus religiosa) trees were observed in the study area.

Month wise surveys were conducted from January, 2003 to December, 2006 to record the number of active nests (nest with eggs). The nests were constantly monitored 2 to 4 consecutive days in a week. A circular plot of $50 \mathrm{~m}$ diameter around the tree on which the nest was located was defined as "nest site". To study the vegetation of nest site, the tree species with more than 20 feet height within the area were recorded along with their density, relative density, height, height of nest from the ground and trunk diameter at breast height (DBH). Height of a tree was measured with the help of Abney level and measuring tape. Canopy diameter was determined by visual estimation using measuring tape. To analyze the relationship between tree height and a canopy radius, and tree height and nest height, a correlation coefficient was calculated. Student's t-test was applied between the characteristics of single and multiple time selected trees and nests to asses the significance of multi use of the nests and analysis was carried out between the tree heights, nest heights, canopy cover, and DBH. It was assumed that the nearer the nest to the tree trunk benefited stronger support and exceeds hide. To examine the hypothesis, placement of the nests on a sub-branch, distance of the nests from the tree trunk, number of nest supporting twigs, and flight pathways were recorded and compared between the multiple and singly used nests by applying 
student's t-test. To determine strong preference for the choice of a particular canopy side located on the edge of a bust road, canopy covers were divided into two categories viz. towards and away from the road. Further, nesting trees located on the edge of the water wells were also taken into an account to study if any preference is made for the part of a canopy which is leaning on the well side. This study aspect would show the tendency of a safer nest site selection in relation to anthropogenic pressure as well anti-predation mechanics.

Along with the study on nesting ecology of the Black ibis, observations were also carried out on other bird species nesting in the same area. Since the Pariah kite (Milvus migrans) was the main coexisting species some times. The inter-specific interactions for nets sites between them recorded into following four categories.

Category I: Use of same nest site or nest tree by both the species in different seasons. Category II: Reuse of deserted nest by other species (i.e., Ibis's nest reused by Pariah kite and vice versa).

Category III: Simultaneous uses of same nest tree without disturbing each other.

Category IV: Displacements of occupant species from its nest by invader species.

\section{Results}

Total 28 nest sites of the Black ibis were located within the study area (Table 1). Majority of the nest sites were located in the heart of rural and urban area and nearby feeding sites. But in rainy season the Black ibis prefers to nest in outskirt of rural and urban area. A pair of the breeding ibis is sitting near the nesting site on khejari tree in the outskirt area The Black ibis preferred nest sites at the trees in the club of number of tree species. Relative density of neem
(Azadirachta indica) and peepal (Ficus religiosa) were significantly higher then other trees in the habitat of the Black ibis. Out of 14 tree species available at nest sites, only two species of trees were utilized for nesting by the Black ibis. The Black ibis was found to nest on peepal and neem trees (Tab. 1). Total 11 (39.28\%) peepal and 17 $(60.71 \%)$ neem trees were selected for nesting. These selected trees comprised $20.37 \%$ of available 54 peepal and $13.82 \%$ of available 123 neem trees in the study area.

Out of 11 peepal nesting trees, 10 $(90.90 \%)$ were located in rural area while 1 (9.09\%) was located in rural area. Likewise, out of 17 neem trees, 2 (11.76\%) nesting neem trees were noted in rural area while 15 $(88.23 \%)$ were observed in urban area. Out of total 28 nest sites $12(42.85 \%)$ nest sites were located in rural area and $16(57.14 \%)$ in the urban area. Among 28 nest sites 14 $(50 \%)$ nest sites were permanent in nature while $14(50 \%)$ were temporary in nature. Among permanent nest site, 14 nest sites, 7 $(50 \%)$ were found in rural area and $7(50 \%)$ in urban area. The similar ratio was found for temporary nesting sites. The ratio of temporary and permanent nesting was 42:58 in rural areas. Among 17 urban nesting sites, $10(58.82 \%)$ were temporary in nature while $7(41.17 \%)$ were of permanent nature. Nesting trees were also used for roosting by this ibis. At one site the Sisham tree was selected for nesting but resulted in nest failure.

The Black ibis more frequently preferred nest on tallest available tree with highest relative density, canopy cover and DBH at nest site (Table 2). The average nest tree height was $8.19 \pm$ SD1.39 $\mathrm{m}$ above ground. The nesting tree height was found to vary from 4.81 to $13.00 \mathrm{~m}$. The nest 
position from the ground was at an average of $6.88 \pm \mathrm{SD} 1.19 \mathrm{~m}$. The nest height varied in the range of 3.84 to $11.02 \mathrm{~m}$. The average canopy cover was $5.67 \pm \mathrm{SD} 1.11 \mathrm{~m}$. The canopy cover was in the range of 3.09 to $9.73 \mathrm{~m}$. Average data on DBH was also observed with an average of $0.63 \pm \mathrm{SD} 0.18$ $\mathrm{m}$. The DBH noted to vary in the range of 0.43 to $1.16 \mathrm{~m}$.

A total of 28 nests of the ibis were studied during the entire study period. Trees selected to nest showed significant correlation between the height and canopy cover $(0.872243, \mathrm{p}=5 \%)$, and total heights of the trees and the nest heights $(0.932416$, $\mathrm{p}=1 \%$ ). Characteristics such as tree height, canopy cover, and nest height of the trees used for nesting once or many times were observed.

All observed nests of the ibis were found to locate on the third sub-branch of the trees (Table 3). Nest placement on the sub-branch of the tree was found with an average of $2.85 \pm \mathrm{SD} 0.32 \mathrm{~m}$ from the end of the trunk. The numbers of flight pathways at each nest site were also counted and it was found with an average of $2.71 \pm$ SD 0.7 and it varied in the range of 1 to 4 .

Table 4 depicts the description of surrounding area of nesting sites. It was observed that in rural area out of 12 nests, 10 nests were located in the heart of rural area in close proximity of human beings while 2 nests were located in outskirt of the rural area. But these outskirt nests were occupied only during rainy season. In urban area out of 16 nests, 14 nests were located in the heart of Churu city and 2 nests were located in the outskirt of the city. Black ibis is a solitary breeder. Therefore, no any tree was having more than one nest. Mostly, roosting trees were selected for nesting. Out of 28 nesting sites, $12(42.8 \%)$ were located near WWB and $9(32.14 \%)$ were near the busy road. On national highway only 3 $(10.71 \%)$ nest were detected, while in the outskirt area the number was $6(21.42 \%)$. In graveyard area only $2(7.14 \%)$ nests were observed whereas in AFH total 9 (32.14\%) nest were observed. Industrial area was the least choice as only 1 (3.57\%) nest was found there. Out of 28 nests, 13 (46.24\%) sites were protected by 10 feet high boundary wall and these sites were safe from predators. In our study it was observed that out of total 28 nesting sites, 21 (75\%) were located near human inhabitation. A nest of House crow was also found $16 \mathrm{ft}$ away from the nest of the Black ibis at peepal tree. Surprisingly, the House sparrow also built a nest underneath the nest of the Black ibis.

\section{Discussion}

The Black ibis prefers neem and peepal trees for nesting. The reason may be the availability, suitable height and canopy of these trees. The selection of nesting trees in birds is also based on the previously performed successful breeding (Klopfer, 1963). Considering the characteristics of the peepal and neem, their larger canopy covers provide number of crotches to support the nest at the proper locations. In breeding months viz., April and May neem (Azadirachta indica) and peepal (Ficus religiosa), the trees usually used by Ibises for nesting come into leaf and may be a factor in nesting. The dense cover of the canopy provides sustained protection by minimizing the direct heat loss in the open sky (Morse, 1980). As per Burger and Hahn (1989), a dense canopy cover reduces the thermal stress to vulnerable young and provides hide from the potential air predators. Moreover, a well covered nest 
K.C. Soni, A.N. Sharma and V.C. Soni / Our Nature (2010) 8: 12-25

Table 1. Record of available and preferred nesting trees at different nesting sites. Nesting site in bold indicate permanent nesting site.

\begin{tabular}{|c|c|c|c|c|}
\hline \multirow{2}{*}{ Nest site } & \multirow{2}{*}{ Location } & \multirow{2}{*}{ Available tree } & \multicolumn{2}{|c|}{ Preferred tree for nesting } \\
\hline & & & Peepal & Neem \\
\hline Hanuman Temple & Depalsar & $\mathrm{P}, \mathrm{N}, \mathrm{Kh}, \mathrm{S}, \mathrm{T}$ & $\mathrm{P}$ & \\
\hline Gandhi Vidya Mandir & Ratan Nagar & $\mathrm{P}, \mathrm{N}, \mathrm{Kh}, \mathrm{T}, \mathrm{S}, \mathrm{R}$ & $\mathrm{P}$ & \\
\hline Balika School & Ratan Nagar & $\mathrm{P}, \mathrm{N}$ & $\mathrm{P}$ & \\
\hline Bhagutha Sidh & Ratan Nagar & $\mathrm{P}, \mathrm{N}, \mathrm{F}, \mathrm{Kh}$ & & $\mathrm{N}$ \\
\hline Pujari Peepal & Ratan Nagar & $\mathrm{P}, \mathrm{N}, \mathrm{Kh}$ & $\mathrm{P}$ & \\
\hline Jalan Sati Mandir & Ratan Nagar & $\mathrm{P}, \mathrm{Kh}, \mathrm{Ka}, \mathrm{N}, \mathrm{G}, \mathrm{R}$ & $\mathrm{P}$ & \\
\hline Rawan Dhora & Ratan Nagar & $\mathrm{P}, \mathrm{N}, \mathrm{Kh}, \mathrm{S}, \mathrm{T}, \mathrm{B}, \mathrm{I}$ & $\mathrm{P}$ & \\
\hline Barath Farm & Nethwa & $\mathrm{P}, \mathrm{N}, \mathrm{Kh}, \mathrm{S}$ & & $\mathrm{N}$ \\
\hline Gaushala Johara & Ramgarh & $\mathrm{P}, \mathrm{N}, \mathrm{Kh}, \mathrm{S}, \mathrm{R}$ & $\mathrm{P}$ & \\
\hline Kacha Johara & Hanutpura & $\mathrm{P}, \mathrm{N}, \mathrm{Kh}, \mathrm{S}$ & $\mathrm{P}$ & \\
\hline RSEB Johara & Bissau & $\mathrm{P}, \mathrm{N}, \mathrm{Kh}, \mathrm{S}$ & $\mathrm{P}$ & \\
\hline Panchayat Well & Buntia & $\mathrm{P}, \mathrm{N}, \mathrm{Kh}, \mathrm{S}$ & $\mathrm{P}$ & \\
\hline Nathji Dhora & Churu & $\mathrm{P}, \mathrm{N}, \mathrm{Kh}, \mathrm{S}, \mathrm{T}, \mathrm{F}, \mathrm{B}, \mathrm{R}$ & & $\mathrm{N}$ \\
\hline Mochiwara & Churu & $\mathrm{P}, \mathrm{N}, \mathrm{Kh}$ & & $\mathrm{N}$ \\
\hline Surana Haveli & Churu & $\mathrm{N}$ & & $\mathrm{N}$ \\
\hline Rishikul & Churu & $\mathrm{P}, \mathrm{N}, \mathrm{B}$ & & $\mathrm{N}$ \\
\hline Old NCC office & Churu & $\mathrm{N}, \mathrm{K}$ & & $\mathrm{N}$ \\
\hline Forest Campus & Churu & $\mathrm{N}, \mathrm{Kh}, \mathrm{P}, \mathrm{S}$ & & $\mathrm{N}$ \\
\hline Johari Sagar & Churu & $\mathrm{P}, \mathrm{N}, \mathrm{J}, \mathrm{R}$ & & $\mathrm{N}$ \\
\hline Yatiji Upasara-south & Churu & $\mathrm{P}, \mathrm{N}, \mathrm{J}, \mathrm{Kh}$ & & $\mathrm{N}$ \\
\hline Yatiji Upasara-East & Churu & $\mathrm{P}, \mathrm{N}, \mathrm{J}, \mathrm{Kh}$ & & $\mathrm{N}$ \\
\hline Yatiji Upasara-West & Churu & $\mathrm{P}, \mathrm{N}, \mathrm{J}, \mathrm{Kh}$ & & $\mathrm{N}$ \\
\hline Yatiji Upasara-North & Churu & $\mathrm{P}, \mathrm{N}, \mathrm{J}, \mathrm{Kh}, \mathrm{R}$ & & $\mathrm{N}$ \\
\hline RIICO Area & Churu & $\mathrm{Sa}, \mathrm{N}, \mathrm{P}, \mathrm{Kh}$ & & $\mathrm{N}$ \\
\hline Pankha Kabristan & Churu & $\mathrm{P}, \mathrm{N}, \mathrm{B}, \mathrm{Sa}, \mathrm{Kh}, \mathrm{R}$ & & $\mathrm{N}$ \\
\hline Karant Balajee & Churu & $\mathrm{P}, \mathrm{N}, \mathrm{Kh}, \mathrm{J}$ & & $\mathrm{N}$ \\
\hline Sethani Johara & Churu & $\mathrm{N}, \mathrm{Kh}, \mathrm{A}$ & & $\mathrm{N}$ \\
\hline Mantrio Ki Chatri & Churu & $\mathrm{P}, \mathrm{N}, \mathrm{B}, \mathrm{Kh}$ & $\mathrm{P}$ & \\
\hline Total preferred nestir & ite $=28$ & & $\begin{array}{l}\mathbf{1 1} \\
\text { (Rural-10) } \\
\text { (Urban-01) }\end{array}$ & $\begin{array}{l}\mathbf{1 7} \\
\text { (Rural-02) } \\
\text { (Urban-15) }\end{array}$ \\
\hline
\end{tabular}

Table 2. Tree height, nest height, canopy cover, and diameter at breast height (DBH) of the nesting tree. Measurements were recorded in meter.

\begin{tabular}{lccccc}
\hline Nest site & $\begin{array}{c}\text { Preferred tree for } \\
\text { nesting }\end{array}$ & $\begin{array}{c}\text { Tree } \\
\text { height }\end{array}$ & Nest height & $\begin{array}{c}\text { Canopy } \\
\text { Cover }\end{array}$ & DBH \\
\hline Hanuman Temple & Peepal & 8.66 & 7.35 & 6.28 & $\begin{array}{c}0.67 \\
\text { Contd.... }\end{array}$
\end{tabular}


K.C. Soni, A.N. Sharma and V.C. Soni / Our Nature (2010) 8: 12-25

Table 2-Contd....

\begin{tabular}{|c|c|c|c|c|c|}
\hline Gandhi Vidya Mandir & Peepal & 8.14 & 7.13 & 6.43 & 0.73 \\
\hline Balika School & Peepal & 13.00 & 11.02 & 9.73 & 1.16 \\
\hline Bhagutha Sidh & Neem & 7.74 & 6.75 & 5.54 & 0.64 \\
\hline Pujari Peepal & Peepal & 9.75 & 6.52 & 5.31 & 0.76 \\
\hline Jalan Sati Mandir & Peepal & 9.80 & 8.56 & 7.19 & 0.97 \\
\hline Rawan Dhora & Peepal & 9.19 & 7.74 & 6.49 & 0.97 \\
\hline Barath Farm & Peepal & 6.91 & 5.58 & 4.33 & 0.76 \\
\hline Gaushala Johara & Neem & 7.54 & 6.25 & 4.93 & 0.51 \\
\hline Kacha Johara & Peepal & 9.66 & 8.05 & 5.21 & 1.04 \\
\hline RSEB Johara & Peepal & 8.81 & 7.40 & 6.18 & 0.70 \\
\hline Panchayat Well & Peepal & 9.22 & 7.60 & 6.27 & 0.49 \\
\hline Nathji Dhora & Peepal & 8.46 & 6.76 & 5.37 & 0.51 \\
\hline Mochiwara & Neem & 7.67 & 6.51 & 5.43 & 0.49 \\
\hline Surana Haveli & Neem & 7.86 & 6.62 & 5.46 & 0.51 \\
\hline Rishikul & Neem & 6.75 & 5.55 & 4.38 & 0.54 \\
\hline Old NCC office & Neem & 7.73 & 7.13 & 5.90 & 0.43 \\
\hline Forest Campus & Neem & 7.85 & 7.17 & 6.07 & 0.52 \\
\hline Johari Sagar & Neem & 7.65 & 6.82 & 5.58 & 0.49 \\
\hline Yatiji Upasara-south & Neem & 7.74 & 6.67 & 5.36 & 0.52 \\
\hline Yatiji Upasara-East & Neem & 7.68 & 6.75 & 5.45 & 0.52 \\
\hline Yatiji Upasara-West & Neem & 7.71 & 6.64 & 5.35 & 0.61 \\
\hline Yatiji Upasara-North & Neem & 4.81 & 3.84 & 3.09 & 0.52 \\
\hline RIICO Area & Neem & 7.59 & 6.56 & 5.90 & 0.58 \\
\hline Pankha Kabristan & Neem & 7.55 & 6.20 & 5.28 & 0.52 \\
\hline Karant Balajee & Neem & 7.25 & 5.85 & 5.00 & 0.58 \\
\hline Sethani Johara & Neem & 8.66 & 7.06 & 5.94 & 0.55 \\
\hline \multirow[t]{2}{*}{ Mantrio Ki Chatri } & Neem & 8.14 & 6.74 & 5.58 & 0.49 \\
\hline & & $\begin{array}{c}X=8.19 \\
S D \pm 1.39\end{array}$ & $\begin{array}{l}X=6.88 \\
S D \pm 1.19\end{array}$ & $\begin{array}{l}X=5.67 \\
S D \pm 1.11\end{array}$ & $\begin{array}{l}X=0.63 \\
S D \pm 0.18\end{array}$ \\
\hline
\end{tabular}

Table 3. Characteristics of the nest location and number of flight pathways.

\begin{tabular}{lccccc}
\hline Nest site & $\begin{array}{c}\text { Preferred } \\
\text { tree for } \\
\text { nesting }\end{array}$ & $\begin{array}{c}\text { Nest placement on } \\
\text { the sub-branch of } \\
\text { the tree }\end{array}$ & $\begin{array}{c}\text { Number of nest } \\
\text { supporting twigs }\end{array}$ & $\begin{array}{c}\text { Nest distance } \\
\text { from the tree } \\
\text { trunk (m) }\end{array}$ & $\begin{array}{c}\text { Flight pathways } \\
\text { approaching the } \\
\text { nest }\end{array}$ \\
\hline Hanuman Temple & Peepal & 2.8 & 4 & 4.1 & 3 \\
Gandhi Vidya Mandir & Peepal & 2.7 & 3 & 3.9 & 3 \\
Balika School & Peepal & 2.9 & 5 & 3.8 & 3 \\
Bhagutha Sidh & Neem & 3.0 & 3 & 3.7 & 4 \\
Pujari Peepal & Peepal & 3.1 & 4 & 4.3 & 2 \\
Jalan Sati Mandir & Peepal & 3.1 & 4 & 4.2 & 3 \\
Rawan Dhora & Peepal & 3.2 & 3 & 3.9 & 4 \\
& & & & & \\
\end{tabular}


K.C. Soni, A.N. Sharma and V.C. Soni / Our Nature (2010) 8: 12-25

Table 3-Contd....

\begin{tabular}{|c|c|c|c|c|c|}
\hline Barath Farm & Peepal & 2.9 & 4 & 4.5 & 3 \\
\hline Gaushala Johara & Neem & 2.9 & 3 & 3.9 & 3 \\
\hline Kacha Johara & Peepal & 2.8 & 5 & 4.3 & 2 \\
\hline RSEB Johara & Peepal & 3.1 & 5 & 4.2 & 2 \\
\hline Panchayat Well & Peepal & 3.2 & 4 & 3.7 & 3 \\
\hline Nathji Dhora & Peepal & 2.9 & 3 & 4.2 & 3 \\
\hline Mochiwara & Neem & 2.9 & 3 & 3.6 & 2 \\
\hline Surana Haveli & Neem & 2.3 & 4 & 3.1 & 1 \\
\hline Rishikul & Neem & 2.8 & 3 & 3.4 & 2 \\
\hline Old NCC office & Neem & 2.9 & 3 & 3.7 & 2 \\
\hline Forest Campus & Neem & 2.7 & 4 & 3.5 & 2 \\
\hline Johari Sagar & Neem & 2.8 & 3 & 4.2 & 2 \\
\hline $\begin{array}{l}\text { Yatiji Upasara- } \\
\text { south }\end{array}$ & Neem & 3.1 & 3 & 4.1 & 3 \\
\hline Yatiji Upasara-East & Neem & 3.0 & 4 & 3.6 & 3 \\
\hline Yatiji Upasara-West & Neem & 1.7 & 3 & 3.8 & 3 \\
\hline Yatiji Upasara-North & Neem & 2.3 & 4 & 3.5 & 3 \\
\hline RIICO Area & Neem & 2.6 & 5 & 3.4 & 2 \\
\hline Pankha Kabristan & Neem & 2.9 & 4 & 4.1 & 4 \\
\hline Karant Balajee & Neem & 3.2 & 4 & 4.2 & 3 \\
\hline Sethani Johara & Neem & 3.3 & 3 & 4.3 & 4 \\
\hline \multirow[t]{2}{*}{ Mantrio Ki Chatri } & Neem & 2.9 & 4 & 3.8 & 2 \\
\hline & & $\begin{array}{c}\mathrm{X}=2.85 \\
\mathrm{SD} \pm 0.32\end{array}$ & $\begin{array}{c}X=3.71 \\
S D \pm 0.71\end{array}$ & $\begin{array}{c}\mathrm{X}=3.89 \\
\mathrm{SD} \pm 0.34\end{array}$ & $\begin{array}{c}X=2.71 \\
S D \pm 0.76\end{array}$ \\
\hline
\end{tabular}

Table 4. Nesting site and description of surrounding area.

\begin{tabular}{lll}
\hline Location & Nest site & Nesting tree area \\
\hline Depalsar & Hanuman Temple & Surrounded by houses, Railway station \\
Ratan Nagar & Gandhi Vidya Mandir & Surrounded by thick wall, Near hospital \\
Ratan Nagar & Balika School & Surrounded by wall and near double story school building \\
Ratan Nagar & Bhagutha Sidh & surrounded by sand dune, near state highway and outskirt of village \\
Ratan Nagar & Pujari Peepal & Surrounded by houses, Tree is cut of this year by House owner \\
Ratan Nagar & Jalan Sati Mandir & Near agriculture farm house \\
Ratan Nagar & Rawan Dhora & Near Onkar ashram and farm house \\
Nethwa & Barath Farm & In agriculture farm house \\
Ramgarh & Gaushala Johara & Near water body and Gaushala \\
Hanutpura & Kacha Johara & Near temporary water body \\
Bissau & RSEB Johara & Near water body and outskirt \\
Buntia & Panchayat Well & Near farm house and tube well \\
Churu & Nathji Dhora & In out skirt of city \\
Churu & Mochiwara & In crowding area \\
Churu & Surana Haveli & Surrounded by big old build ings \\
Churu & Rishikul & Near station road and electric line pass through the Neem tree \\
Churu & Old NCC office & Near Nai sarak, now market complex is developed in the campus and no \\
& & nesting from 2005 onwards \\
Churu & Forest Campus & Surrounded by proscopis trees
\end{tabular}



Table 4-Contd....

K.C. Soni, A.N. Sharma and V.C. Soni / Our Nature (2010) 8: 12-25

\begin{tabular}{lll} 
Churu & Johari Sagar & Near waste water body \\
Churu & Yatiji Upasara-south & Near waste water body \\
Churu & Yatiji Upasara-East & Near waste water body \\
Churu & Yatiji Upasara-West & Near waste water body \\
Churu & Yatiji Upasara-North & Near waste water body \\
Churu & RIICO Area & In industrial sector \\
Churu & Pankha Kabristan & In Mus lim graveyard and busy road \\
Churu & Karant Balajee & Near School and out side of Churu city \\
Churu & Sethani Johara & Out skirt of city and Gurjar Dhani \\
Churu & Mantrio Ki Chatri & In old city \\
\hline
\end{tabular}

does not require wing shading provided by parents to their chicks, which considerably reduces energy loss to the parents. Like Hadadah ibis, the Black ibis build nest on the upper third of the nest tree.

A positive correlation between tree height, canopy and nest height makes nesting successful. The height and higher nest elevation provides easy access to escape when there is a danger by the ground predator. Although non-significant differences between DBH of permanent nesting tree and temporary trees has supported the theory of safer site selection based on an experience of no collapsing of the nest during occupancy; but least related to the size of the tree at its base. A choice of the nest height in birds seems to be determined with the consideration of climatic pressures such as wind speed, temperature, sudden and heavy rain pour, and potential predation including human disturbance (Dhinsa et al., 1989).

The significant variation in the supporting twigs of the nest shows the sturdier the nest happened to be selected repeatedly. The nest placement on the subbranch and its distance from the trunk has significance of minimizing exposer, easy flight pathways and escape. Beside the characteristics of the tree and nest vicinity, consideration of the foraging sites in imminent horizon is also equally important. The Black ibis tends to build nest near the feeding sites. Similarly, Kushlan (1976) reported that the American White ibis (Eudocimus albus) select the nesting colony site depending on the availability of the foraging habitat. Olga and Jose (1989) also observed that the Egyptian vulture (Neophron percnopterus) builds nests at the site where the food availability is abundant.

Many bird species are reported to occupy previously used nesting area (Catchpole, 1972; Greenwood and Harvey, 1976; Harvey et al., 1979; Newton, 1979; 1982; Aumann, 1989; Warkentin et al., 1991). Breeding site fidelity was more often observed in the successful individuals than the unsuccessful one (Darley et al., 1977; Newton, 1982; Coulson and Thomas, 1983; Shields, 1984; Gavin and Bollinger, 1988; Gauthier, 1990; Beletskey and Orians, 1991). It is probably because of familiarity to an area which may permit to take advantages of favourable foraging, predator avoidance and nesting site that enhance reproductive success (Hinde, 1956; Greenwood and Harvey, 1982). Similarly nesting nearby the roost site is also advantageous for the same. This seems quite possible factor affecting nest site selection by the Black ibis as the entire nest sites were also used as roost sites throughout the 
year. Black ibis preferred to nest nearby the roost sites that may be due to familiar environment and their location mainly near the foraging sites and hence facilitate easy settlement of breeding pairs. Similar pattern of colony site selection was observed in White ibis in which breeding colony formation was initiated by displaying males at roost site during day time (Kushlan, 1976). Availability of food is another factor affecting nest site selection. In some localities, roost sites and nest sites of the White ibis were often shifted from one site to the other depending on food availability (Kushlan, 1976). In White ibis the colony site fidelity was observed due to adequate food availability even-though drastic nesting failure recorded after tidal washout (Frederick, 1987).

Reuse of old deserted nests and takeover active nests were recorded in many bird species as a consequence of scarcity of nest sites or nest materials (Dusi, 1968; Burger, 1978a; 1978b).Nesting association of the Black ibis with crows and sparrows may be due to shortage of nesting sites. Such an association is also reported in other ibises (Donazar et al., 1996). Stealing of nest material was recorded occasionally in some ibises due to the same reason (Urban, 1974; Sahin, 1982). The Black ibises often reuse their conspecific or heterospecific deserted nests. However, stealing of nest material by the Black ibis was not recorded during the present study. By preferring old nests, the ibis could save energy required in search of safer nest site and by shortening the period of Nidification. Frequent flights are required to gather nest material from nearby area to build a nest and each flight consumes on average $0.25 \mathrm{kcal} / \mathrm{m}$ energy (Pennycuick and De Santo, 1989). Thus, male Black ibis has to invest much time and energy to build a new nest. Therefore, reuse of nest involves apparent benefit of time and energy saving by not building a new nest. It is further supported by the fact that early pre-laying period found significantly shorter when a pair reused old nest. If the same pair reuses the site, then it could minimize the cost of territory establishment. It also acts beneficiary by skipping prolong virtues of courtship. This would facilitate the possibilities of repetition of breeding in a one calendar year.

The nesting trees selected for nesting near the water resources were comparatively bigger in size due to their good growth. The good canopy of these trees provided suitable nesting sites as far as thermal heat regulation is concerned. Urbanisation is uprooting the nesting trees of the birds, so also with the Black ibis. Thus the ibis preferred to nest on the trees along with the roads inspite of their exposure to wind and noise of traffic. It can be concluded that the Black ibis whether built nest near the water resources, road sites, city sites garden sites and agriculture fields, they were near the feeding grounds.

Nesting of the ibis in a colony was reported by Naik (1989) and Mundkur (1991). Chavda (1997) has observed the ibis nesting on one of the Palm species with the White Backed Vulture in the Gir forest, India. Ali and Ripley (1983) have reported 3 to 4 nests of the ibises on a single tree. Further, it has been sighted that the majority of the Ciconiiformes species are known to be a colonial breeder. According to Lack (1968), birds which feed solitarily used the nest solitarily. Though, the ibis is a Ciconiiformes and a flock feeder, it was found to be mainly solitary breeder by nature. Beside all above mentioned evidences, it shows that such a divert 
K.C. Soni, A.N. Sharma and V.C. Soni / Our Nature (2010) 8: 12-25

behaviour has been apparently set forth an adaptation following the availability of food. Hence, flexibility has been developed to avoid any potential competition for the breeding as well on the restricted foraging ground. This could be compared with the mixed colonial egrets and herons, which also maintain a certain distance among their nests depending upon their body size for the comfort and to avoid competition (Burger, 1978a).

\section{Acknowledgements}

I am highly thankful to UGC, CRO, Bhopal for providing financial assistance for this work in the form of minor research project and to Prof. P.C. Frederick, University of Florida), Dr. K.L. Bildstein (Director research, Hawk mountain sanctuary, PA) and Dr. M.C. Coulter (Chair person, SIS Group) for providing valuable literature and guidance.

\section{References}

Alatalo, R.V., A. Lunderberg and S. Ulfstrand 1985. Habitat selection in the Pied Flycatcher Ficedula hypoleuca. In Habitat selection in birds (Ed. M.L. Cody), Academic Press, Orlando, FL. pp. 59-83.

Ali, S. and S.D. Ripley 1983. Handbook of the birds of India and Pakistan. Oxford University Press, Bombay. 733 p.

Alonso, J.A., R. Munoz-Pulido and L.M. Bautista 1991. Nest site selection and nesting success in the Azure winged Magpie in central Spain. Bird Study 38: 45-51.

Ames, P.L. and G.S. Merserau 1964. Some factors in the decline of the Osprey in Connecticut. Auk 81: $173-185$

Aumann, T. 1989. Breeding parameters of the Brown Goshawk, Accipiter fasciatus, in south-eastern Australia. Eти 89: 112-118.

Beletskey, L.D. and G.H. Orians 1991. Effects of breeding experience and familiarity on site fidelity in female Red-Winged Blackbirds. Ecology 72: 787-796.

Bertram, B.C.R. 1978. Living in groups: predators and prey. In Behavioural ecology: an evolutionary approach (Eds. J.R. Krebs and N.B. Davies), Blackwell Scientific Publications, Oxford. pp 221-248.

Bogliani, G., M. Fasola, L. Canova and N. Saino 1992. Foraging rhythm and chick diet in Little Terns in three Adriatic coastal wetlands. Avocetta 16: $31-34$.

Boulinier, T. 1996. On breeding performance, colony growth and habitat selection in Buff-Necked Ibis. Condor 98: 440-441.

Bouton, S.N. and T.C. Bouton 2001. Interspecific interactions and nest building behaviour in Buff-necked Ibis in the Brazilian Pantanal. Waterbirds 24(2): 294-295.

Brown, J.L. 1969. Territorial behaviour and population regulation in birds. Wilson Bull. 81: 293-329.

Burger, J. 1978a. The pattern and mechanism of nesting in mixed species heronries. In Wading birds (Eds. A. Sprunt, J. Odgen and S. Winkler). RES. Rep. No. 7. Natl. Aud. Soc., N.Y. pp. 45-48.

Burger, J. 1978b. Competition between Cattle Egret and native North American herons, egrets and ibises. Condor 80: 15-23.

Burger, J. 1979. Resource partitioning: nest site selection in mixed species colonies of herons, egrets and ibises. Am. Midl. Nat. 101(1): 191210.

Burger, J. 1984. Colony stability in Least Terns. Condor 86: 61-67.

Burger, J. and C. Hahn 1989. Crow predation on Black-crowned Night Heron eggs. Wilson Bull. 89: 350-351.

Burger, J. and L.M. Miller 1977. Colony and nest site selection in White faced and Glossy Ibises. Auk 94: 664-676.

Cain, A.P. and N. Hilgarth 1974. Nesting relationship between Columba palumbus and Milvus migrans Donana. Acta Vertebrata 1(2): 97102.

Catchpole, C.K. 1972. A comparative study of territory in the Reed Warbler (Acrocephalus 
K.C. Soni, A.N. Sharma and V.C. Soni / Our Nature (2010) 8: 12-25

scirpaceus) and Sedge Warbler (A.schoenobaenous). J. Zool. (Lond.) 166: 213-231.

Chavda, P.B. 1997. Studies on some ecological aspects of the Indian Black Ibis, Pseudibis papillosa (Temminck) at Junagarh and its surrounding area. Department of Bioscience, Saurastra University. Rajkot, India. (Ph.D. Thesis)

Collias, N.E. and E.C. Collias 1984. Nest building and bird behaviour. Princeton Univ. Press, Princeton, NJ.

Coulson, J.C. 1968. Differences in the quality of birds nesting in the centre and on the edge of a colony. Nature 217: 478-479.

Coulson, J.M. and C.S. Thomas 1983. Mate choice in the Kittiwake Gull. In Mate choice (Ed. P. Bateson), Cambridge Univ. Press, London. pp. 361-376.

Darley, J.A., D.M. Scot and N.K. Taylor 1977. Effects of age, sex, and breeding success on site fidelity of Gray catbirds. Bird Banding 48: 145-151.

Dhinsa, S.M., E.K. Peter and A.B. David 1989. Nest height of Black-Billed Magpies: Is it determined by human disturbance or habitat type? Can. J. Zool. 67: 228-232.

Dhondt, A.A., B. Kempenaers and F. Adriaensen 1992. Density dependent clutch size caused by habitat heterogeneity. J. Anim. Ecol. 61: 643648.

Donazar, J.A., A. Travaini, A. Rodriguez, O. Ceballos and F. Hiraldo 1996. Nesting association of Raptors and Buff-necked Ibis in the Argentinean Patagonia. Colonial Waterbirds 19: 11-115.

Donazar, J.A., O. Ceballos, A. Travaini, A. Rodriguez, M. Funes and F. Hiraldo 1994. Breeding performance in relation to nest site substratum in a Buff-necked Ibis (Theristicus caudatus) population in Patagonia. Condor 96: 9941002.

Dunham, M.L. 1990. Nest site selection by Boat tailed Grackles. Wilson Bull.102: 702-706.

Dusi, J.L. 1968. The competition between Cattle Egrets and Little Blue Herons. Alabama Birdlife 16: 4-6.
Frederick, P.C. 1986. Conspecific nest take overs and egg destruction by White Ibises. Wilson Bull. 98: 156-157.

Frederick, P.C. 1987. Chronic tidally induced nest failure in a colony of White Ibises. Condor 89: 413-419.

Fretwell, D.S. and H.L. Lucas 1974. On territorial behaviour and other factors influencing habitat distribution in birds. Acta Bioth. 19: 16-36.

Gauthier, G. 1990. Philopatry, nest site fidelity and reproductive performance in Buffle Heads. Auk 107: 126-132.

Gavin, T.A. and E.K. Bollinger 1988. Reproductive correlates of breeding site fidelity in Babolinks (Dolichonyx aryzivorous). Ecology 69: 96103.

Greenwood, P.J. and P.H. Harvey 1976. The adaptive significance of variation in breeding area fidelity in Black Bird (Turdus merula). J. Anim. Ecol. 45: 887-898.

Greenwood, P.J. and P.H. Harvey 1982. The natal and breeding dispersal of birds. Annu. Rev. Ecol. Syst.13: 1-21.

Hancock, J., J.A. Kushlan and M.P. Kahl 1992. Storks, Ibises and Spoonbills of the world. Academic Press, London. 385 p.

Harvey, P.H., P.J. Greenwood and C.M. Perrins 1979. Breeding area fidelity of Great Tit (Parus major). J. Anim. Ecol. 48: 305-313.

Hinde, R.A. 1956. The biological significance of the territories of birds. J. Anim. Ecol. 98: 340-369.

Jackson, S.L., D.S. Hik and R.F. Rockwell 1988. The influence of nesting habitat on reproductive success of Lesser Snow Geese. Can. J. Zool. 66: 1699-1703.

Kelly, J.P. 1993. The effect of nest predation on habitat selection by dusky flycatchers in limber pine juniper woodland. Condor 95: 8393.

Klopfer, P. 1963. Behavioural aspects of habitat selection: the role of early experience. Wilson Bull.75: 15-22.

Koplin, J.R. and R.S. Hoffmann 1968. Habitat overlap and competitive exclusion in volves (Microtus). Am. Midl. Nat. 80: 494-507. 
K.C. Soni, A.N. Sharma and V.C. Soni / Our Nature (2010) 8: 12-25

Kushlan, J.A. 1976. Site selection for nesting colonies by the American White Ibis Eudocimus albus in Florida. Ibis 118: 590-593.

Lack, D. 1954. The natural regulation of animal numbers. Oxford University Press, Oxford. $343 \mathrm{p}$.

Lack, D. 1968. Ecological adaptations for breeding in birds. Methuen and Co., London. 409 p.

Lathigara, R. 1989. Behavioural and ecological studies on population census, roosting,

foraging, feeding and breeding of the Indian Black Ibis at Jamnagar, India. Saurastra Univ., Rajkot, India. (M.Sc. Thesis)

Li, P. and T.E. Martin 1991. Nest site selection and nesting success of cavity nesting birds in high elevation forest drainages. Auk 108: 405-418.

MacArthur, R.H. and R. Levis 1967. The limiting similarity, convergence and divergence of coexisting species. Am. Nat.101: 377-385.

Martin, T.E. 1988. Processes organizing open nesting bird assemblages: competition or nest predation? Evol. Ecol. 2: 37-50.

Martin, T.E. and J.J. Rooper 1988. Nest predation and nest site selection of a western population of the Hermit Thrush. Condor 90: 51-57.

McCrimmon, D.A. 1980. The effects of timing of breeding, dispersion of nests, and habitat selection on nesting success of colonial waterbirds. Trans. Linn. Soc. (New York) 9: 87-102.

Morse, D.H. 1980. Behavioural mechanisms in ecology. Harvard Univ. Press, Cambridge, Massachusetts. 383 p.

Mundkur, T. 1991. Nesting and feeding ecology of aquatic birds in Saurashtra and gulf of Kachchh. Department of Bioscience, Saurashtra University, Rajkot, India. (Ph.D. Thesis)

Naik, S. 1989. Heronry at Indrapur. Newsletter for Birdwatchers (11:12): 5 .

Nair, A. and R. Vyas 2003. Nesting records of Black ib is (Pseudibis papillosa) in Kota district, Rajasthan. Zoos Print 18(3): 1050.

Newton, I. 1979. Population ecology of raptors. Poyser, Berkhamsted. 399 p.
Newton, I. 1982. Fidelity to breeding area and mate in Sparrow Hawks (Accipiter nisus). J. Anim. Ecol. 51: 327-341.

Newton, I. 1991. Habitat variation and population regulation in Sparrow Hawks. Ibis 133: 76-88.

Nillson, S.G. 1984. The evolution of nest site selection among hole nesting birds: the importance of nest predation and competition. Ornis Scand. 15: $167-175$.

Nillson, S.G. 1987. Limitation and regulation of population density in the nuthatch Sitta europaea breeding in natural cavities. J. Anim. Ecol. 56: 921-937.

Norrdahl, K., J. Suhonen, O. Hemminki and E. Korpimaki 1995. Predator presence may benefit kestrels protect curlew nests against nest predators. Oecologia 101: 105-109.

Olga, C. and A.D. Jose 1989. Factors influencing the breeding density and nest site selection of the Egyptian Vulture Neophron percnopterus. J. Orn. 130(5): 353-359.

Pennycuick, C.J. and T.L. De Santo 1989. Flight speeds and energy requirements for White Ibises on foraging flights. Auk 106: 141-144.

Rendell, W.B. and R.J. Robertson 1989. Nest site characteristics, reproductive success and cavity availability for tree swallows breeding in natural cavities. Condor 91: 875-885.

Ricklefs, R.E. 1969. An analys is of nesting mortality in birds. Smithson Contrib. Zool. 9: 1-48.

Ryder, P.L. and J.R. Ryder 1981. Reproductive performances of Ring billed Gulls in relation to nest location. Condor 83: 57-60.

Sahin, R. 1982. Contribution to reproductive behaviour of the free living Bald Ibises (Geronticus eremite L.) in Trukey. 1. Communication: Arrival, Pair formation and nesting. Okol. Vogel 4: 181-190.

Schoener, T.W. 1974. Resource partitioning in ecological communities. Science 185: 27-39.

Shields, W.M. 1984. Factors affecting nest and site fidelity in Adirondack Barn Swallows (Hirundo rustica). Auk 101: 780-789.

Simmons, R. and P.C. Smith 1985. Do Northern Harriers (Circus cyaneus) choose nest sites adaptively? Can. J. Zool. 63: 494-498. 
K.C. Soni, A.N. Sharma and V.C. Soni / Our Nature (2010) 8: 12-25

Soni, K.C. 2008. Study on population, foraging, roosting and breeding activities of the Black ibis (Pseudibis papillosa) inhabiting the arid zone of Rajasthan, India. Department of Zoology, M.D.S. University, Ajmer, India. (Ph.D. thesis)

Soni, K.C. and A.N. Sharma 2006. Effects of environmental stress on population, foraging, roosting and breeding activities of Indian Black ibis (Pseudibis papillosa) in and around churu city of Rajasthan. In Environmental degradation and management Vol. II. (Eds.

K.S. Vishwakarma and K.C. Soni). pp. 49-56.

Soni, K.C. and A.N. Sharma 2008. Breeding ecology of the Black ibis (Pseudibis papillosa) in the arid zone of Rajasthan, India.pp.63-72. In Biodiversity conservation and Human Well being (Eds. B.R. Rao, S.N. Prasad, C. Srinivasalu and P. Judson), Department of Zoology, Osmania University, Hyderabad, Andhra Pradesh

Tuomenpuro, J. 1991. Effect of nest site on nest survival in the Dunnock, Prunella modularis. Ornis Fenn. 68: 49-56.
Urban, K.E. 1974. Breeding of Sacred Ibis (Threskiornis aethiopica) at lake Shala, Ethiopia. Ibis 116(3): 263-277.

Warkentin, I.G., P.G. James and L.W. Oliphant 1991. Influence of site fidelity on mate switching in urban breeding Merlins, Falco columbarius. Auk 108: 294-302.

Watson, J. 1992. Nesting ecology of the Seychelles Kestrel Falco araea on Mahe, Seychelles. Ibis 134: 259-267.

Wiens, J.A. 1976. Population responses to patchy environments. Ann. Rev. Ecol. Syst. 7: 81-120.

Wiklund, C.G. 1982. Fieldfare (Turdus pilaris) breeding success in relation to colony size, nest position and association with merlins (Falco columbarius). Behaviour. Ecol. Sociobiol. 11: 165-172.

Wittenberg, J.F. and G.L. Hunt 1985. The adaptive significance of coloniality in birds. In Avian Biology (Eds. D.S. Farner, J.R. King and K.C. Parkes), Vol. VIII. Academic Press, New York. pp. 1-78. 